\title{
左右ボールねじカウンタバランス制振機構と超高速スピンドルを 搭載したエ作機械によるマイクロドリル加エに向けた基礎研究
}

\section{廣垣 俊樹*1, 青山 栄一 ${ }^{* 1}$, 山下 竜弥 ${ }^{* 2}$, 岸本 昌大 ${ }^{* 2}$, 河添 佑矢 ${ }^{* 2}$ \\ Fundamental study on machine tools equipped with vibration suppression mechanism based on left and right ball screw and with an ultra-high speed spindle for micro-drilling}

\author{
Toshiki HIROGAKI ${ }^{* 1}$, Eiichi AOYAMA*1, Tatsuya YAMASITA*2, \\ Masahiro KISHIMOTO ${ }^{* 2}$ and Yuya KAWAZOE*2 \\ ${ }^{* 1}$ Department of Mechanical Engineering, Doshisha University \\ 1-3 Tatara-Miyakodani, Kyotanabe-shi, Kyoto 610-0321, Japan \\ ${ }^{*}$ Graduate School at Doshisha University \\ 1-3 Tatara-Miyakodani, Kyotanabe-shi, Kyoto 610-0321, Japan
}

Received: 11 February 2017; Revised: 12 April 2017; Accepted: 30 May 2017

\begin{abstract}
Recently, the miniaturization and multi-functionalization of electronic equipment have been demanded due to developments in IT. Therefore, the miniaturization and densification of the semiconductor package printed wiring boards (PWBs) have been more demanded. For the realization, the miniaturization of PWBs and fabrication of highly dense electrical circuit layers are also demanded. As a result, problems such as broken drill by the increase in aspect ratio and heat damage around the drilled hole are occurred in micro-drilling process of the PWB. A step feed drilling is considered to be effective as a solution to those problems However, it needs a high-speed reciprocating movement in short stroke to keep a drilling efficiency, and then causes residual vibration on machine tool table. In the present report, we propose a novel machine tool equipped with a counter balance mechanism using a left and right lead ball screw. This mechanism consists of a balance mass that moves in the Z-axis direction corresponding to the spindle movement to cancel a vibration force in linear direction at reciprocating movement. We construct a test stand to estimate the reducing effect of vibration force and to mode it. Moreover, we confirm the improving effect in high speed micro-drilling process with a proposed machine tool.
\end{abstract}

Key words : Machine tools, Micro drill, Printed wiring boards, High speed spindle, Counter balance,Vibration

\section{1. 緒言}

近年，携帯電話やノートパソコンなどに代表される電子機器の軽薄短小化，多機能化が求められている．各種 電子機器の CPU に用いられる半導体パッケージ基板は, 半導体素子をプリント基板上に配置して回路接続により その高度な機能を具現化している. Si ウエー八の微細加工および集積回路化技術が向上する一方，当該プリント 基板における回路接続用スルーホールのマイクロドリル加工技術の高度化（今村他，2005）も求められる．例え ば，量産では 500×600 mm サイズ量産基板で 30 万穴以上のマイクロドリル加工が必要となる. そのため半導体パ ッケージ基板のドリル加工用の工作機械では, 毎分 16 万回転を超える回転数の超高速エアスピンドルが搭載され, ドリル直径 $200 \mu \mathrm{m}$ 以下の極小径マイクロドリルによる毎秒 4 5穴 (4〜 hits/s) 加工の技術が具現化されている. しかしながら本分野における研究例は少なく,ドリルの振れ回りの影響などについて僅かに報告例 (Watanabe et al, 2008）（佐藤他，2014）がある程度である.

\footnotetext{
No.17-00052 [DOI:10.1299/transjsme.17-00052], J-STAGE Advance Publication date : 9 June, 2017

*1 正員, 同志社大学理工学部（广 $610-0321$ 京都府京田辺市多々羅都谷 1-3）

*2 同志社大学大学院

E-mail of corresponding author: thirogak@mail.doshisha.ac.jp
} 
そこでプリント基板の極小径マイクロドリルを用いた加工現象において，著者らはドリルの小径化による工具 の熱容量の低下と加工時の温度上昇の関係に着目して, 穴周辺（穴壁面）に熱変質層を生じない制約条件下でド リル加工条件を設定する手法を検討してきた（廣坦他，2008）。しかしながら，加工穴の穴位置精度やドリル折損 の改善方法については十分な検討には至っていなかった。 また業界の現状はノンステップ加工で遂行されている 場合が多いようである. その理由としては, 1 穴に対して複数回の Z 軸ステップ動作では加工能率の確保が難しいため とされてきた. その一方で，益々小径化するプリント基板のマイクロドリル加工の技術において，切りくず詰ま りを抑制しドリルの折損防止などに複数回のステップ加工は将来的に極めて有効な手法になる（寺林他，2002） （岩田他，1983）と考えられる．そこで先行研究では穴位置精度とドリル折損性の改善を目的に，工作機械の送 り軸モータの負荷容量も考慮しながら, 加工能率を低下させることなく極小径マイクロドリル加工のステップ動 作において各ステップのストロークおよび送り速度の組み合わせ最適化の手法を提案し, その有効性を示した(廣 垣他, 2012). その一方で, 数 Hz に達する Z 軸ステップ送り運動に起因する残留振動の抑制が課題として残った. そこで本研究では, 毎分 16 万回転を超える回転数の超高速エアスピンドルを用いた極小径マイクロドリル向けに 左右同軸ボールねじを有する工作機械を考案し, そのカウンタバランスによる穴あけ動作時の低振動化を考察す る. 特に本報ではテストスタンドを試作してその制振機構の基本原理の基礎的な解明を遂行し，さらに工作機械 を用いてのドリル実加工における効果を検証する。

\section{2. 実験装置および試料}

\section{$2 \cdot 1$ 提案する制振機構の実験装置および計測装置}

(株) タケウチ製たて型プリント基板用数值制御高速 1 軸穴あけ機 ND-122L の主軸に WESTWIND 製マイクロ エアドリルスピンドル D1733（最高回転数は 250krpm）を取り付けて極小径マイクロドリルでのスルーホール加 工を遂行する場合を対象とする. 本機は, 左右ボールねじを用いたカウンタバランス機構（制振機構）の搭載, また前報(廣垣他, 2012)を参考にして Z 軸サーボモータの容量の増強（カウンタ分の可動部の重量が増大寸る点 も考慮し), 主軸に固定された穴位置測定用カメラの設置により加工と穴位置精度の評価を機上統合したプロトタ イプ機である. 本工作機械におけるカウンタバランス機構とは, 図 1 のようにスピンドル部 $\left(M_{\mathrm{s}}\right)$ とカウンタ部 $\left(M_{\mathrm{c}}\right)$ が逆ねじのボールねじ（左右ボールねじ）で直列に接続され，上下運動を行う際にサーボモータに近いカウンタ ウェイトがサーボモータから遠いボールねじ先端のスピンドル部と逆向きの運動をすることで, Z 方向の直進軸 バランスを保ち, 反転運動時の振動の低減が期待できるものである．ただしカウンタ機構分だけ利用できる Z 軸 ストロークが短くなるが，極小径マイクロドリルが対象とする穴深さは数 $\mathrm{mm}$ 程度であり実用上はほとんど問題 ないレベルである. またプリント基板用穴あけ工作機械では加工時の基板押え機構や切り屑集塵などが附属し， それらが複雑で初期基礎モデルの検討には向かない，そこで基本原理の解明のために，本機をモデルにして THK 製直動システム KR30H10 に同様に左右ボールねじを搭載したテストスタンド（図 2) を試作して主な検討を進め る. 図 2 にはその上視写真および側面からの断面図を示す. 工作機械とテストスタンドの主要パラメータを表 1 に示す．また，各部分の加速度を計測するため PCB Piezotronics 製の圧電型 3 軸加速度計 356B21 を用いた.

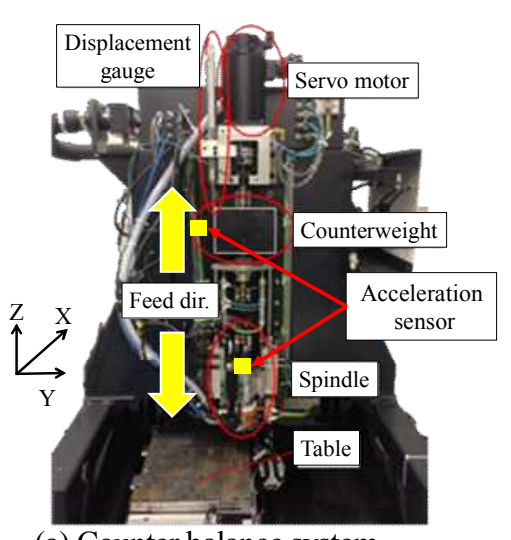

(a) Counter balance system

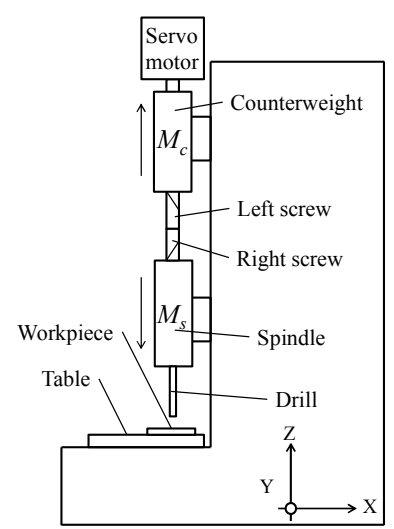

(b) Schematic of machine tool

Fig. 1 Machine tool equipped with counter-balance mechanism. 


\section{$2 \cdot 2$ 加工試料および工具}

加工試料には，複合材料の一種で日立化成（株）製板厚 $0.8 \mathrm{~mm}$, 銅䈃厚さ $18 \mu \mathrm{m}$ の FR4 両面銅張積層板（以 下，PWB と称す）を使用した。 母材はエポキシ樹脂で強化繊維は E ガラスである. また加工時の摩擦熱によっ て加工壁面に同心円状に熱損傷（B-ring）の有無を確認するため（廣垣他，2008），PWB と同様な材質で厚さ 0.1 $\mathrm{mm}$ の 1 層材も重初て同時に加工した. エントリーボードとして鈴鹿金属（株）製板厚 $0.2 \mathrm{~mm}$ のアルミニウム板

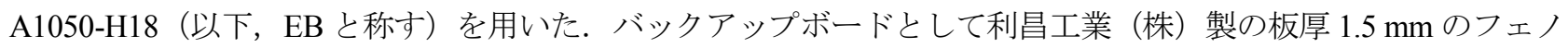
ール板 PS-1160F（以下，BB と称す）を用いた. マイクロドリルはユニオンツール（株）製超硬アンダーカット

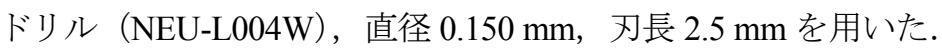

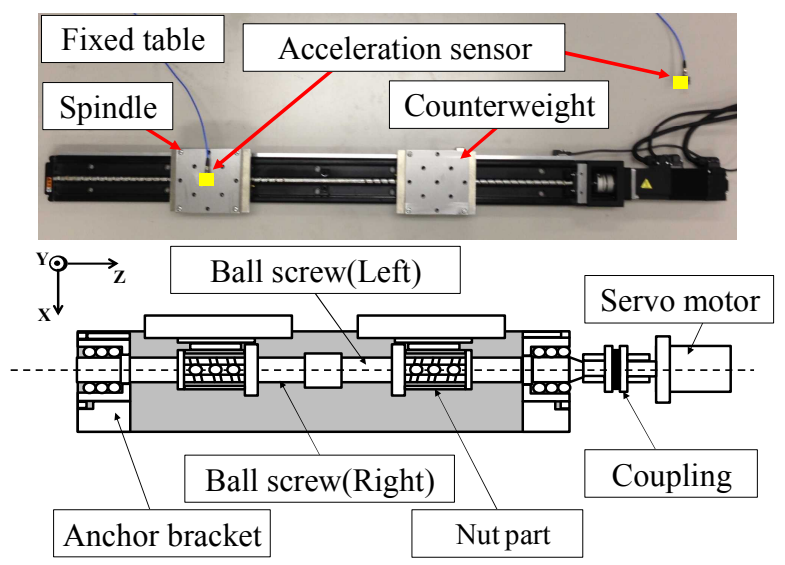

Fig. 2 Teststand with right and left and right lead ball screw

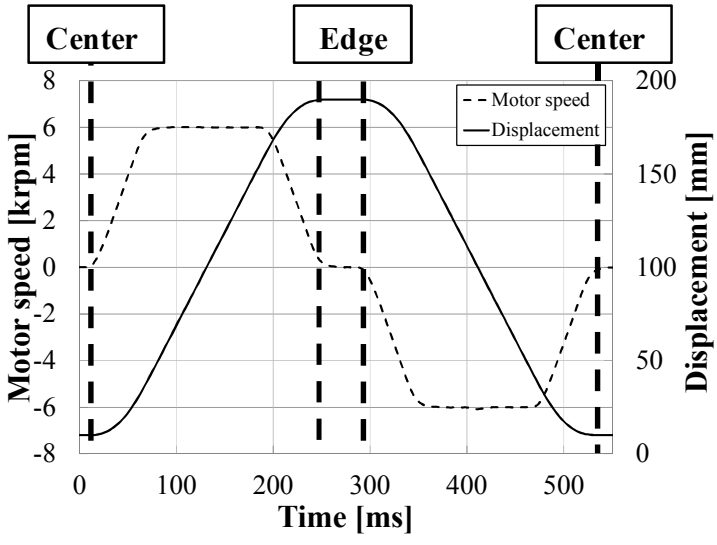

Fig. 3 Commanded motor speed and position

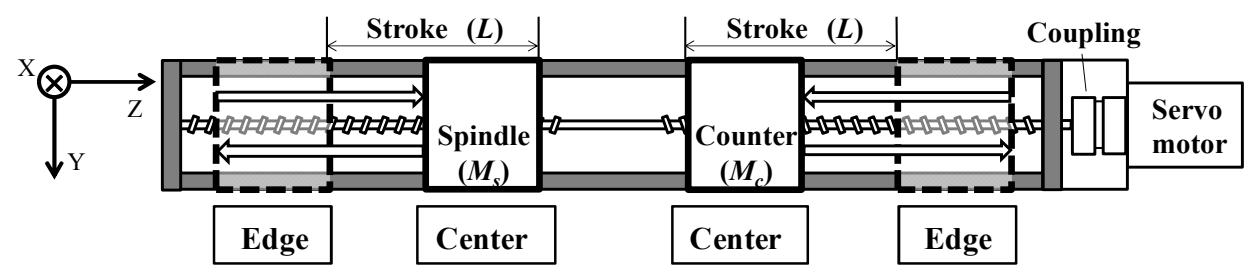

Fig. 4 Definition of commanded movement.

Table 1 Parameters of teststand and machine tools.

\begin{tabular}{c|c|c}
\hline Machine type & Teststand & Machine tool \\
\hline Stroke (One side) $[\mathrm{mm}]$ & 180.0 & 2.1 \\
\hline Maximum stroke $($ One side) $[\mathrm{mm}]$ & 215.4 & 86.0 \\
\hline Ball screw lead $[\mathrm{mm}]$ & 10.0 & 16.0 \\
\hline Ball screw diameter $\phi[\mathrm{mm}]$ & 10.0 & 20.0 \\
\hline Weight of spindle $[\mathrm{kg}]$ & 2.0 & 10.0 \\
\hline
\end{tabular}

\section{3. 実験方法および評価方法}

\section{$3 \cdot 1$ 動作実験の条件および加工条件}

テストスタンドは図 3 の破線で示寸台形波の回転速度を入力して動作させた．図中の実線はそのときの位置関 係を示す．この動作は等速で一定区間を往復する動作である．その際のテストスタンドの動きを図 4 に示す．テ ストスタンドは市販の作業机（固定台）上に水平または鉛直方向に固定，またはスポンジ上に水平にフリーで置 いた場合を評価の対象とした. テストスタンドの指令の最高速度は $600,1000 \mathrm{~mm} / \mathrm{s}$ とした. 工作機械でも同様に ノンステップドリル加工の動作を行った．図５に工作機械での実験における各区間の速度の定義および位置関係 を示す．本報は主に基礎実験を目的としており，さらに加工実験は穴位置精度への振動の影響を顕著にするため 
に，ノンステップ加工とした. ワークは，上から EB， PWB， BB の順（総板厚 $2.5 \mathrm{~mm}$ ）に重ねて行い， $\mathrm{EB}$ 上面 から $1.2 \mathrm{~mm}$ (図 5 中の $h_{1}$ ) の深さまで加工を行った. 加工パスは, 隣り合う加工穴中心間距離 $0.35 \mathrm{~mm}$ の格子型 加工パスとし，量産時のドリル寿命（吉川他，2007）の知見に基づき連続で 3,000 穴の加工とした. 主軸回転数 $n$ は $240 \mathrm{krpm}$ とした. これら加工条件を表 2 に示す.

\section{$3 \cdot 2$ 評価方法}

\section{$3 \cdot 2 \cdot 1$ 振動加速度の計測}

工作機械においては，図 1(a)中に示すように振動加速度はスピンドル部および Z 軸筐体部の 2 箇所で X,Y,Z 方 向の 3 方向を測定した. テストスタンドにおいては図 2 上視写真に示すスピンドル部（可動部）と固定台，さら にスポンジ上の実験では X,Y,Z の直進 3 方向だけでなく, それらの軸のまわりの回転方向の成分との切り分けの ために Y 軸上に 2 箇所, $\mathrm{Z}$ 軸上に 2 箇所で計測（詳細は図 22）して検討した. 加速度データより周波数解析して 加速度スペクトル密度 (以下, ASD と称す) を求めた.さらに加速度データからのスペクトログラム解析の手法 も導入した. スペクトログラム解析とは, 加速度データを短時間毎に区切り FFT 解析を行ったグラフである. ASD と比べ時間軸が存在するという利点がある．近年，音声認識など時系列で周波数特性が変化する分野でパターン マッチングなどの処理と融合して，その発展性が期待されてきている手法の一つである（野村他，2004）。困 3, 4 に示す時間軸に合わせたスペクトログラムの例を図 6 に示す. これは台形波動作 1 動作分の解析の例である.

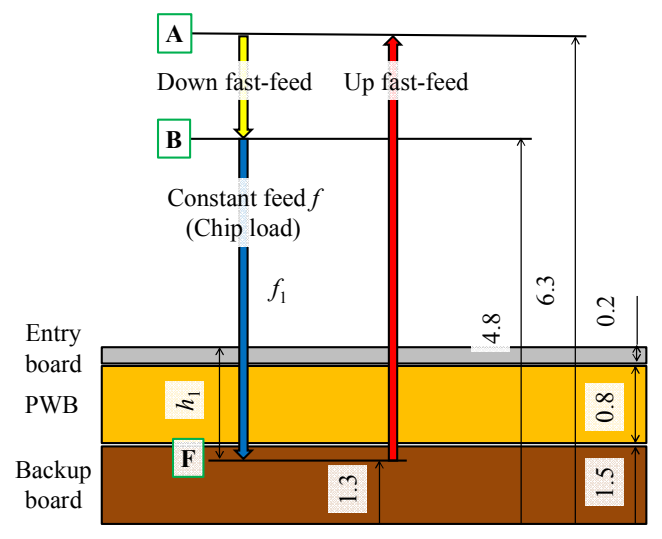

Table 2 Processing conditions of non-step drilling.

\begin{tabular}{|c|c|c|c|}
\hline Drill diameter $[\mathrm{mm}]$ & \multicolumn{3}{|c|}{0.15} \\
\hline Spindle speed [krpm] & \multicolumn{3}{|c|}{240} \\
\hline Step & \multicolumn{3}{|c|}{1} \\
\hline$f_{1}[\mu \mathrm{m} / \mathrm{rev}]$ & \multicolumn{3}{|c|}{8.0} \\
\hline$h_{1}[\mathrm{~mm}]$ & \multicolumn{3}{|c|}{1.20} \\
\hline Up fast-feed [m/min] & \multicolumn{3}{|c|}{10.0} \\
\hline Down fast-feed [m/min] & \multicolumn{3}{|c|}{10.0} \\
\hline Weight ratio $\alpha$ & 0.12 & 0.66 & 1.00 \\
\hline Number of holes & \multicolumn{3}{|c|}{3000} \\
\hline 2 hole center distance $[\mathrm{mm}]$ & \multicolumn{3}{|c|}{0.35} \\
\hline
\end{tabular}

Fig.5 Stroke during one-hole drilling.

\section{3-2 - 2 穴位置精度}

穴位置精度に関しては，穴の中心座標を穴位置とし，工作機械が指令した穴位置と実際加工された穴の位置と の X,Y 方向の中心間距離の差で定義する. また, 加工穴の測定には主軸搭載 CCD カメラ $(800 \times 600=48$ 万画素, 分解能 $4 \mu \mathrm{m}$ ）により 3 の倍数列の穴位置を 1000 穴撮影した画像の解析を用いた. 各穴の NC 指令位置でカメラ 画像の穴輪郭の画素の重心を算出し当該穴の中心位置とし，各穴で中心位置と NC 指令位置との誤差をそれぞれ $D X[\mu \mathrm{m}], D Y[\mu \mathrm{m}]$ と定義し，それらをプロットした図 7 の例（図中の $D X_{\mathrm{g}}, D Y_{\mathrm{g}}$ はプロットの重心位置）で精度の 評価を行う.

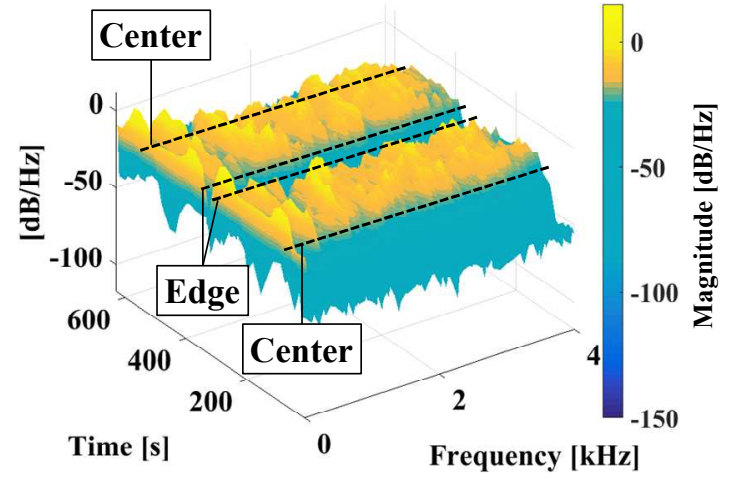

Fig. 6 An example of analyzed spectrogram.

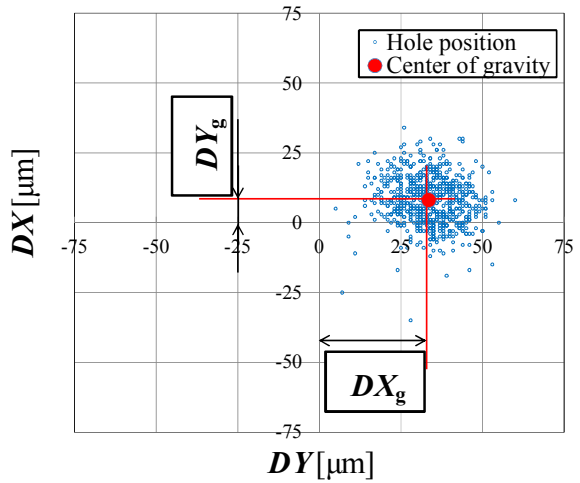

Fig. 7 Definition of hole position accuracy. 


\section{$3 \cdot 2 \cdot 3$ 鉛直送り Z 軸のサ一ボ内部情報を用いたスピンドル重量の同定法}

カウンタバランス制振機構において, 各種の附属部品を含むスピンドル可動部の重量が非常に重要である。そ こで，カウンタ側に搭載するカウンタ重量を変更しながら， Z 軸サ一ボロック時のサーボ内部のトルク情報を用 いてその重量を同定した。工作機械は安川電機製サーボなので同社製 SigmaWin+, テストスタンドは三菱電機製 サーボなので同社製 MR Configurator2 を用いてサーボモータ内部情報とエンコーダからトルク值を取得した. 図 8 に計測したトルクデータをカウンタ重量別に示す. 静止摩擦力分の誤差を含むと考えられるが, 図 8 より停止 トルクは $0 \mathrm{~N} \cdot \mathrm{m}$ となる点でテストスタンド，工作機械スピンドル部の重量は $2.0 \mathrm{~kg}$ およ゙ $10.6 \mathrm{~kg}$ と同定された.

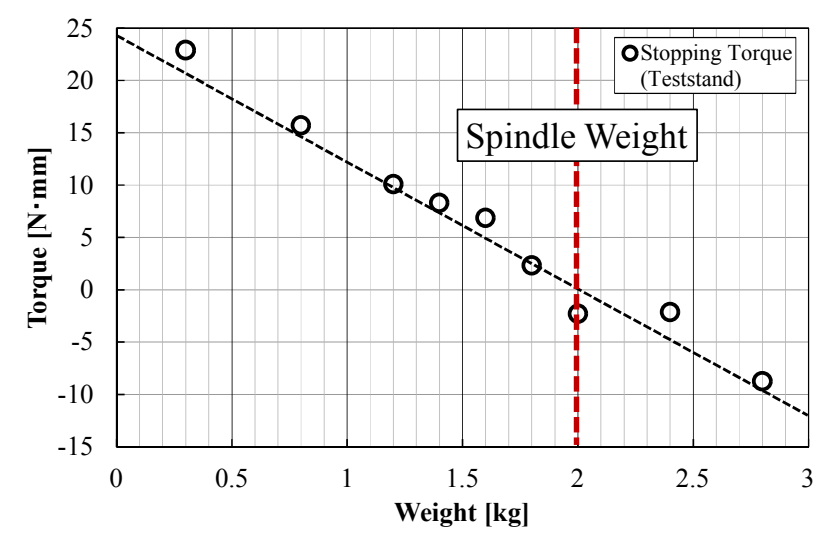

(a) Teststand

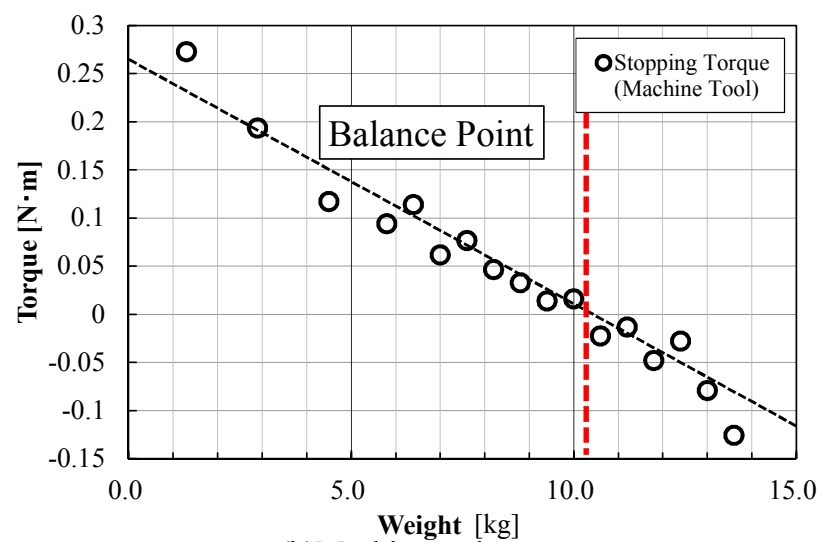

(b)Machine tool

Fig. 8 Identification of stopping torque.

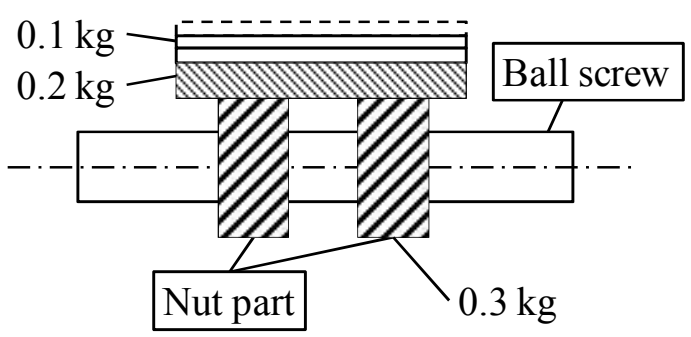

(a) Teststand

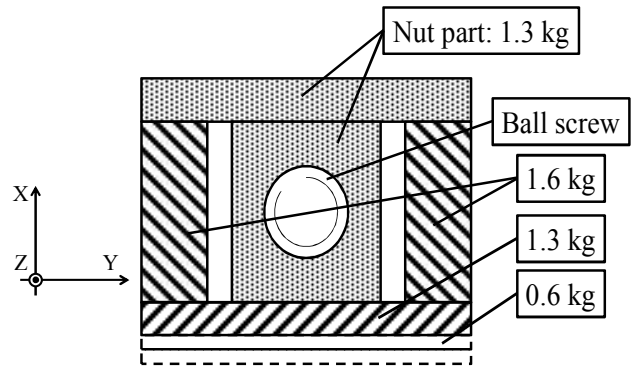

(b)Machine tool

Fig. 9 Structure of counter weight.

\section{$3 \cdot 2 \cdot 4$ カウンタウェイト}

図 2 よりテストスタンドはカウンタ側, スピンドル側のどちらも可動重量の変更が可能であり，図 1 より工作 機械はカウンタ部の重量のみの変更が可能である．前節の方法で同定した各部の重量も含めて，それぞれの重量 積載位置の断面図（それぞれZ-X断面と Y-X 断面）を図９に示す．ここでカウンタ部とはボールねじ上で送り軸 サーボモータに近い可動部であり，スピンドル部とはサーボモータに遠い側の可動部となる：そこで $\alpha=M_{c}$ (カ ウンタ部重量） $/ M_{s}$ (スピンドル部重量）を重量比と定義し，この $\alpha$ を変化させその影響を調べた。本報では $M_{s}$ を一定として $M_{c}$ のみを変化させた。 それぞれの実験で用いた重量比と $M_{s}, M_{c}$ の関係を表 3，4に示す.

Table 3 Conditions of weight ratio (Teststand).

\begin{tabular}{c|c|c|c|c|c|c|c|c}
\hline Weight ratio $\alpha$ & 0.15 & 0.40 & 0.60 & 0.70 & 0.80 & 1.00 & 1.20 & 1.40 \\
\hline$M_{s}[\mathrm{~kg}]$ & \multicolumn{8}{|c}{2.0} \\
\hline$M_{c}[\mathrm{~kg}]$ & 0.3 & 0.8 & 1.2 & 1.4 & 1.6 & 2.0 & 2.4 & 2.8 \\
\hline
\end{tabular}

Table 4 Conditions of weight ratio (Machine tool).

\begin{tabular}{c|c|c|c|c|c|c|c|c|c|c|c|c|c|c}
\hline \hline Weight ratio $\alpha$ & 0.12 & 0.42 & 0.55 & 0.60 & 0.66 & 0.72 & 0.77 & 0.83 & 0.89 & 0.94 & 1.00 & 1.05 & 1.11 \\
\hline$M_{s}[\mathrm{~kg}]$ & \multicolumn{10}{|c}{10.6} \\
\hline$M_{c}[\mathrm{~kg}]$ & 1.3 & 4.5 & 5.8 & 6.4 & 7.0 & 7.6 & 8.2 & 8.8 & 9.4 & 10.0 & 10.6 & 11.2 & 11.8 \\
\hline
\end{tabular}




\section{4. 解析 - 実験結果および考察}

\section{$4 \cdot 1$ テストスタンドのボールねじ駆動機構のモデル化とパラメータの同定}

本駆動機構をモデル化するにあたり，軸方向振動，ねじり振動の両振動を考慮するため，ボールねじの 4 慣性 モデルを直列に接続したものを用いた. カウンタ部，スピンドル部は同一のボールねじ上に接続されており，そ れぞれの質点位置でねじり振動が発生していると考えられる.さらにボールねじはモータ側と反モータ側の支持 形態が固定一支持であるシングルアンカ構造をしており，スピンドル側ではラジアル方向のみを拘束する形とな っている. 以上を考慮して作成した力学モデルを図 10 に示す.この力学モデルは 7 慣性モデルであり，7自由 度系 $\left(\theta_{m}, \theta_{b r}, \theta_{b l}, Z_{b r}, Z_{b l}, Z_{c}, Z_{s}\right)$ である. 運動方程式を式（1）から式（6）また，モデル図のボールねじの軸方向剛 性・ねじり剛性, ナットの軸方向剛性, 回転 - 直動の変換係数, 各部分における慣性モーメントの同定方法は参 考文献（松原他，2008）を用いた. 用いた式を式（7）から式（14）に示す.

また, 同定したパラメータは $T_{m}[\mathrm{Nm}]$ (モータトルク), $\theta_{m}[\mathrm{rad}]$ (モータ回転角), $\theta_{b r}, \theta_{b l}[\mathrm{rad}]$ (ボールねじ回転角), $z_{b r}, z_{b l}[\mathrm{~m}]$ (ボールねじ位置) $, z_{c}, z_{s}[\mathrm{~m}]$ (位置), $J_{m}=1.05 \times 10^{-5}\left[\mathrm{kgm}^{2}\right]$ (モータの慣性モーメント), $J_{b r}=2.30 \times 10^{-6}$, $J_{b l}=2.40 \times 10^{-6}\left[\mathrm{kgm}^{2}\right]$ （ボールねじ慣性モーメント）, $D_{m}=0.00\left[\mathrm{kgm}^{2}\right]$ (モータ軸部摩擦係数),$D_{b r}=5.00 \times 10^{-9}$, $D_{b l}=5.00 \times 10^{-9}\left[\mathrm{kgm}^{2}\right]$ (ねじ軸部摩擦係数) $, C_{c}=50.0, C_{s}=50.0\left[\mathrm{kgm}^{2}\right]$ (リニアガイド部摩擦係数) $, M_{c}, M_{s}=2.00$ $[\mathrm{kg}]$ (重量), $M_{b r}=0.19, M_{b l}=0.19[\mathrm{~kg}]$ (ボールねじ重量)， $K_{g r}=150.00 ， K_{g l}=760.00[\mathrm{Nm} / \mathrm{rad}]$ (ボールねじねじ り剛性), $K_{b}=7.50 \times 10^{8}[\mathrm{~N} / \mathrm{m}]$ （支持軸受の軸方向剛性）， $K_{s r}=5.50 \times 10^{6}, K_{s l}=10.30 \times 10^{5}[\mathrm{~N} / \mathrm{m}]$ (ねじ軸の軸方向 剛性), $K_{n r}=5.50 \times 10^{7}, K_{n l}=5.50 \times 10^{7}[\mathrm{~N} / \mathrm{m}]$ (ナットの軸方向剛性), $R_{r}[\mathrm{~m} / \mathrm{rad}]$ (回転-直動の変換係数)， $R_{l}[\mathrm{~m} / \mathrm{rad}]$ (回転-直動の変換係数),$l_{p}=0.01$ （リード）， $R\left(R=l_{p} / 2 \pi\right)$ である. 減衰係数 $C, D$ は作成したモデルにトルク を入力した際に，最も実際の運動に近くなる值で同定した。添字の r, 1， c， s はそれぞれ右ねじ，左ねじ，力ウ ンタ部，スピンドル部である。またナットの位置がストロークの中央の場合である.

$$
\begin{array}{rl}
\boldsymbol{M} \ddot{\boldsymbol{z}}+\boldsymbol{C} \dot{\boldsymbol{z}}+\boldsymbol{K} \boldsymbol{z}=\boldsymbol{f} & \boldsymbol{x}=\left[\begin{array}{lcccccc}
\theta_{m} & \theta_{b l} & \theta_{b r} & z_{b l} & z_{b r} & z_{c} & z_{s}
\end{array}\right]^{\mathrm{T}} \\
\boldsymbol{f} & =\left[\begin{array}{cccccccc}
T_{m} & 0 & 0 & 0 & 0 & 0 & 0
\end{array}\right]^{\mathrm{T}} \\
\boldsymbol{M} & =\left[\begin{array}{cccccccc}
J_{m} & 0 & 0 & 0 & 0 & 0 & 0 \\
0 & J_{b l} & 0 & 0 & 0 & 0 & 0 \\
0 & 0 & J_{b r} & 0 & 0 & 0 & 0 \\
0 & 0 & 0 & M_{b l} & 0 & 0 & 0 \\
0 & 0 & 0 & 0 & M_{b r} & 0 & 0 \\
0 & 0 & 0 & 0 & 0 & M_{c} & 0 \\
0 & 0 & 0 & 0 & 0 & 0 & M_{s}
\end{array}\right] \\
\boldsymbol{C} & =\left[\begin{array}{cccccccc}
D_{m} & 0 & 0 & 0 & 0 & 0 & 0 \\
0 & D_{b l} & 0 & 0 & 0 & 0 & 0 \\
0 & 0 & D_{b r} & 0 & 0 & 0 & 0 \\
0 & 0 & 0 & 0 & 0 & 0 & 0 \\
0 & 0 & 0 & 0 & 0 & 0 & 0 \\
0 & 0 & 0 & 0 & 0 & C_{c} & 0 \\
0 & 0 & 0 & 0 & 0 & 0 & C_{s}
\end{array}\right]
\end{array}
$$




$$
\begin{aligned}
& \boldsymbol{K}=\left[\begin{array}{ccccccc}
K_{g l} & -K_{g l} & 0 & 0 & 0 & 0 & 0 \\
-K_{g l} & K_{g r}+K_{g l}+R^{2} K_{n l} & -K_{g r} & R K_{n l} & 0 & -R K_{n l} & 0 \\
0 & -K_{g l} & K_{g r}+R^{2} K_{n r} & R K_{n r} & R K_{n r} & 0 & -R K_{n r} \\
0 & R K_{n l} & 0 & K_{n l}+K_{b s} & 0 & -K_{n l} & 0 \\
0 & 0 & R K_{n r} & K_{n r}-K_{s r} & K_{n r}+K_{s r} & 0 & -K_{n l} \\
0 & -R K_{n l} & 0 & -K_{n l} & 0 & K_{n l} & 0 \\
0 & 0 & -R K_{n r} & -K_{n r} & -K_{n r} & 0 & K_{n r}
\end{array}\right] \\
& J_{b l}=\frac{m_{b l}\left(D \times 10^{-3}\right)^{2}}{8} \\
& J_{b r}=\frac{m_{b r}\left(D \times 10^{-3}\right)^{2}}{8} \\
& J_{m}=J_{m r}+J_{c}+\frac{J_{b l}}{2} \\
& K_{n l}= \\
& K_{n r}=0.8 \times K \times\left(\frac{F_{a o}}{0.1 \times C_{z}}\right)^{\frac{1}{3}} \\
& K_{g l}=\frac{\pi\left(\frac{S_{l} \times E}{L_{l}}\right) \times 10^{9}}{\left(32 L_{l}\right) \times 10^{9}} \\
& K_{s r}=\left(\frac{S_{r} \times E}{L_{r}}\right) \times 10^{9} \\
& \left(32 L_{r}\right) \times 10^{9}
\end{aligned}
$$

$D:$ 軸径, $J_{m r}, J_{c}$ : 慣性モーメント, $K$ : 剛性理論値, $F_{a o}$ : 軸方向荷重, $S_{l}$ : 逆ねじの断面積, $S_{r}$ : 順ねじの断 面積, $L_{l}$ : 逆ねじの長さ, $L_{r}$ : 順ねじの長さ, $E$ : 縦弾性係数, $G$ : 横弾性係数, $d:$ ボールねじの谷径である.

\section{$4 \cdot 2$ テストスタンドのカウンタバランス制振機構の振動特性の解析と実験結果 \\ $4 \cdot 2 \cdot 1$ Z 軸方向の送り機構の周波数応答の解析結果と実測値との比較}

図 10 のモデルに基づき送り機構のボールねじ軸の軸方向振動とねじり振動の周波数応答を検討する. 重量比 $\alpha$ の変化を変化させながら計算結果と実測值の比較を遂行する. 解析には The MathWorks 社の Simulink を使用し, その際のブロック線図を図 11 に示寸，図 10 のモデルによるZ 軸方向のモータトルクからモータ角速度までの周 波数応答関数の解析結果を図 12 , さらに図 13 はその $1000 \mathrm{~Hz}$ 以下の拡大を示寸. 図 12 における $800 \mathrm{~Hz}$ 付近まで の振動のピークは図 10 中の軸方向 $Z_{b r}, Z_{b l}, Z_{c}, Z_{s}$ で振動変位が生じており, 図 13 に示すように $700 \mathrm{~Hz}$ 付近から力 ウンタ部重量を増加させるにつれて，ピークが低周波側に移行しているため，高周波側の振動はカウンタ側のね じ軸の影響を大きく受けた振動（以下，カウンタ軸方向振動と称す）である. 200〜 300 Hz 付近のピークは重量 比 $\alpha$ の変化に対して周波数変化がみられないことからスピンドル側の礼じ軸の影響を大きく受けた振動（以下， スピンドル軸方向振動と称す) である. またこれらの共振ピークの周波数の差は $M_{c}, M_{s}$ の質量の差や比と関係が 深く $\alpha \fallingdotseq 1$ に近い設定では動吸振器に近い特性を示寸こともわかる. 一方で $1200 \mathrm{~Hz}, 2500 \mathrm{~Hz}$ の高い周波数のピ 


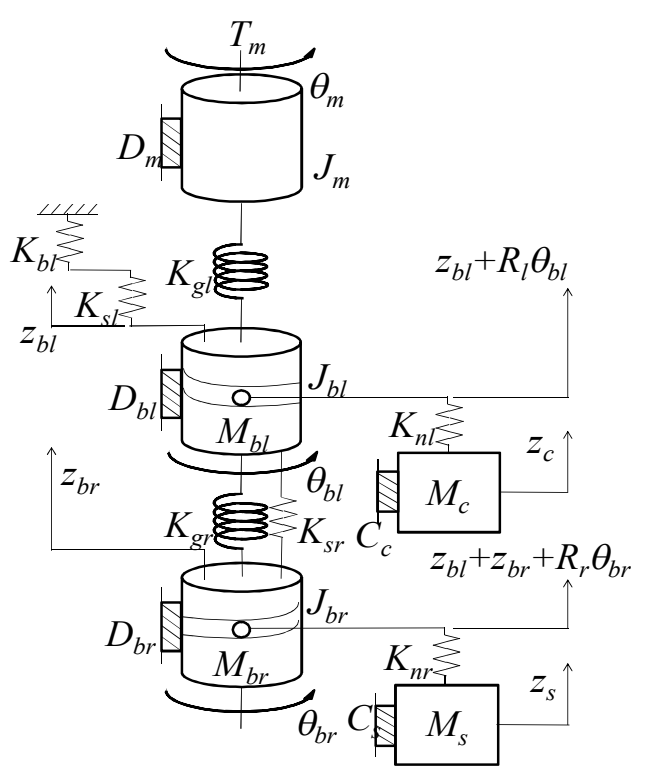

Fig.10 Feed driving model.

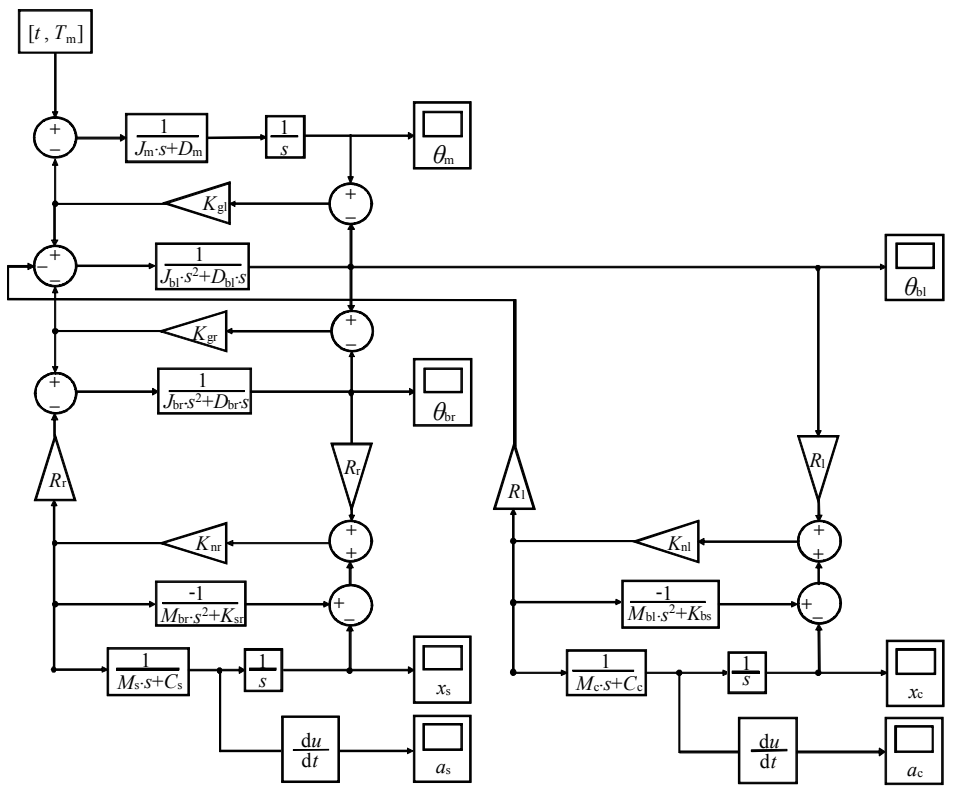

Fig. 11 Block diagram of feed driving model.

一クは図 10 中のねじり方向 $\theta_{m}, \theta_{b r}, \theta_{b l}$ に振動変位が生じている. ねじり振動は重量比 $\alpha$ の増加に伴って増加する 傾向がみられた．またボール称じ上に $M_{c}$ を付加したため共振周波数の数は増大寸ることもわかるが，制御系に 悪影響を与えるような場合にはノッチフィルタの設定数を増や寸などで対応は可能であると考えられる.

図 14 にMR Configurater2 を用いて測定したテストスタンドにおけるモータトルクからモータ角速度までの周波 数応答関数の測定值を示寸. 図 14 における $200 \sim 300 \mathrm{~Hz}$ の振動はスピンドル軸方向振動, 300 700 Hz の振動はカ ウンタ軸方向振動であると予想できる. また， $1200 \mathrm{~Hz}, 2700 \mathrm{~Hz}$ 付近の振動はどちらもねじり振動に起因してい ると考えられる．振幅，位相に多少のズレはあるものの周波数ピーク位置は一致した．したがって，この機構の 動作中の周波数応答の解析には図 10 のモデルが有効であることがわかった.

次に台形波の動作中におけるスピンドル部 Z 軸方向の加速度データからスペクトログラム解析を行った. 計測 の際, 動作による影響を明確に把握するため, テストスタンドをスポンジ上に設置 (以下, スポンジ実験と称す) して図 2 のZ-X 平面を水平面として実験を行った． $\alpha=1.00$ における解析結果を図 15 (a)（b）に示す.これは台 形波動作 1 動作分を解析した結果である. 剛性値は $L_{l}, L_{r}$ (モータ支持軸受からナットまでの距離）に反比例し, 共振周波数は剛性の 0.5 乗に比例することから, ナット位置が時間 $t$ に対して変化して移動する場合には共振周 波数も時間に対して変化すると考えられる. 図 15 (b) より $t=100 \mathrm{~ms}$ で $950 \mathrm{~Hz}$ より $t=280 \mathrm{~ms}$ には $1300 \mathrm{~Hz}$ 一 変化した後, $t=390 \mathrm{~ms}$ で $1300 \mathrm{~Hz}$ より $t=570 \mathrm{~ms}$ には $950 \mathrm{~Hz}$ に変化する振動ピークがみられる.この周波数の 振動は, 解析結果においてカウンタ側の㸚じ軸の影響を大きく受けたねじり振動（以下，カウンタねじり振動と 称す）に起因していることがわかる. 図 14 から同様に $2700 \mathrm{~Hz}$ 付近にはスピンドル側のねじ軸の影響を大きく受 けた周波数の時間変化を伴うねじり振動（以下，スピンドルねじり振動と称す）に起因していると予測できる. ここで軸方向振動を調べるため， $\alpha=1.00$ における $800 \mathrm{~Hz}$ までの解析結果を図 16 (a) (b) に示寸. 図 16 (a) (b) より $t=700 \mathrm{~ms}$ で $420 \mathrm{~Hz}$ より $t=1000 \mathrm{~ms}$ には $340 \mathrm{~Hz}$ に変化し, $t=1100 \mathrm{~ms}$ で $340 \mathrm{~Hz}$ より $t=1400 \mathrm{~ms}$ には $420 \mathrm{~Hz}$ に変化する振動が存在する. この振動も㸚じり振動と同様に考えると低周波側がスピンドル軸方向振動, 高周波 側がカウンタ軸方向振動であることがわかる. 寸なわち厳密には，ナットの位置により共振の周波数も変化する こともわかる。

\section{$4 \cdot 2 \cdot 2$ Z 軸の運動時に機構から生じる強制外カに起因する振動}

図 15，16 から送り駆動系単体としての基本特性は把握できた. しかしながら, 加工精度を考える場合には工作 機械の共振周波数などに近いさらに低い周波数帯に対する検討が必要と考えられる. すなわち機構の運動に起因 して生じる $100 \mathrm{~Hz}$ 以下の強制外力による振動に着目した。ここでは工作機械の Z 軸が鉛直軸であることを考慮 して，テストスタンドを垂直に配置した状態でスピンドル部（可動部）と固定台の X, Y,$Z$ 軸振動を計測しそ 


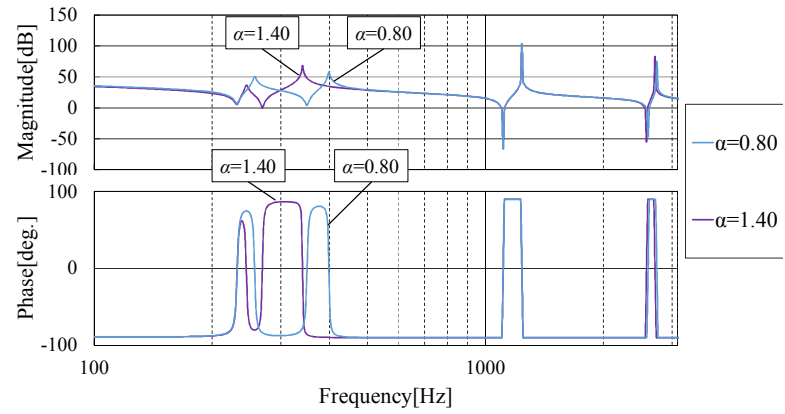

Fig. 12 Simulation of frequency response (Teststand).

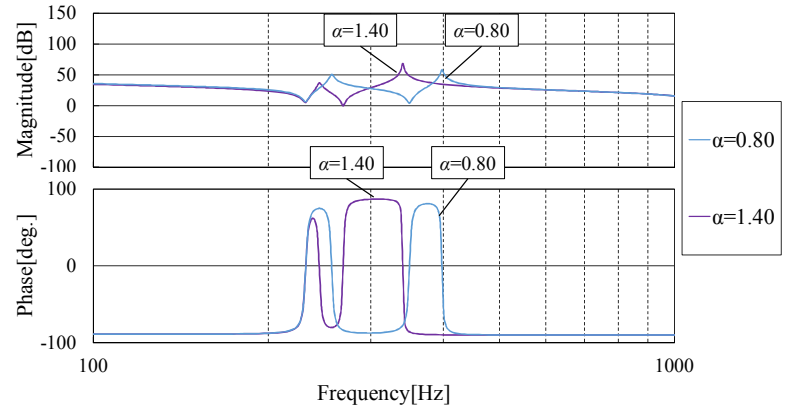

Fig. 13Axial vibration (Teststand).

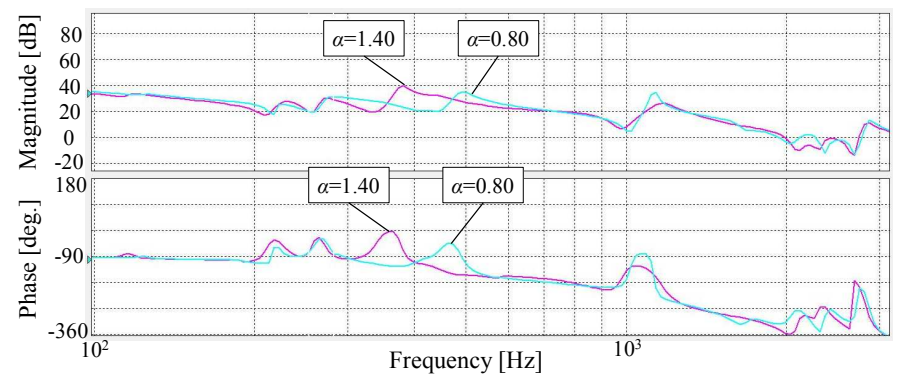

Fig. 14 Measured value of frequency response (Teststand).

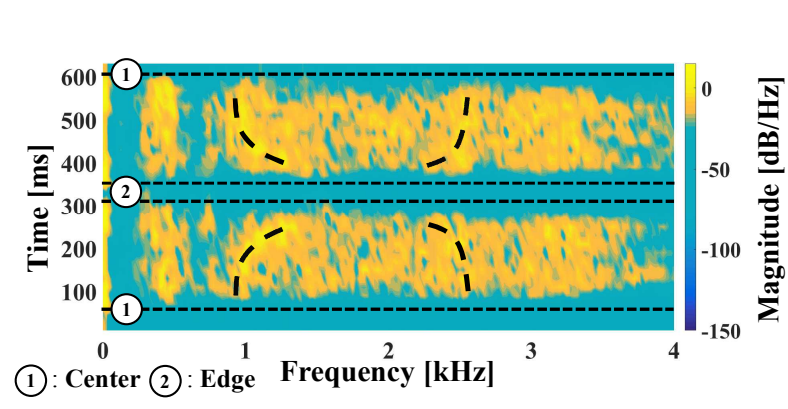

(a) Spectrogram analysis to $4000 \mathrm{~Hz}(\alpha=1.00)$

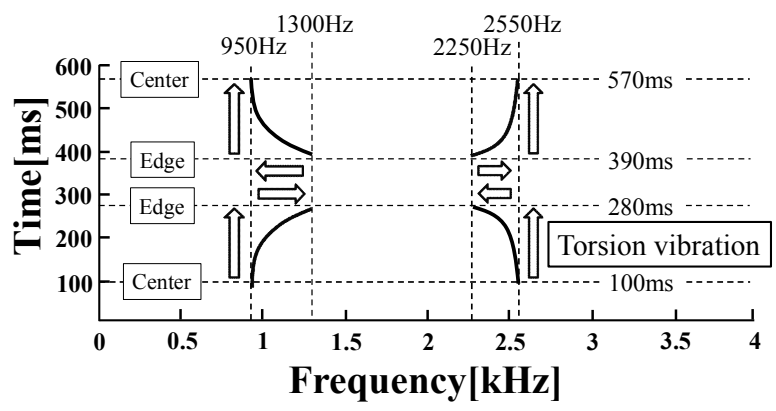

(b) Frequency variation

Fig. 15 Spectrogram analysis of torsion vibration in Z-axis (Teststand) $(\alpha=1.00)$.

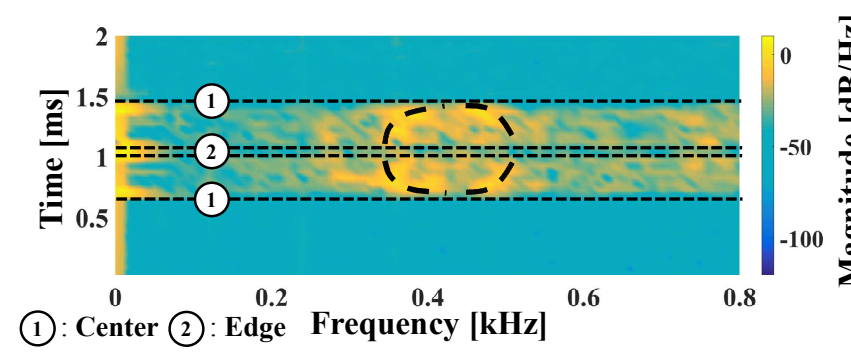

(a) Spectrogram analysis to $800 \mathrm{~Hz}(\alpha=1.00)$

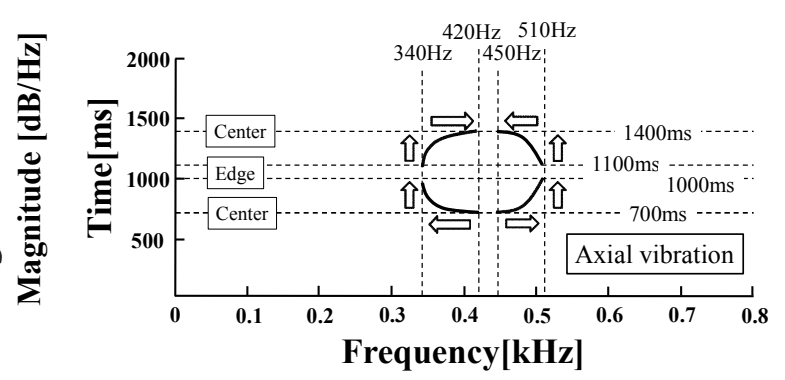

(b)Frequency variation

Fig. 16 Spectrogram analysis of axial vibration in Z-axis (Teststand $)(\alpha=1.00)$.

の ASD を調べた。すなわち図 3 に示す台形波の速度で連続した往復動作中の ASD を観察して, その中で質量比 $\alpha$ を変更した時に連動して振動の周波数ピークが変化する成分を調べた．その結果，往復動作周期の逆数に近い $2.2 \mathrm{~Hz}$ とその 5 倍の $11 \mathrm{~Hz}$ にその変化が顕著あり,これらを機構の運動時の強制外力の代表値として考察を進める.

固定台における結果を図 17 (a) (b) に示寸. 固定台 $2.2 \mathrm{~Hz}$ の振動では，3 方向ともに重量比 $\alpha=0.80$ において 極小值を示した. また $11 \mathrm{~Hz}$ の振動では，3 方向ともに重量比 $\alpha=1.00$ において極小值を示した. スピンドル部で は $2.2 \mathrm{~Hz}$ の X,Y 軸方向振動, $11 \mathrm{~Hz}$ の Z 軸方向振動に図 18 (a)（b) に示寸同様に極小值を示す傾向が見られた. またスピンドル部 $2.2 \mathrm{~Hz}$ の振動では重量比 $\alpha=0.80$ で極小值を示しながら, また $11 \mathrm{~Hz}$ では $\alpha=1$ で極小值を示し 
ながら, 重量比の増加に伴って振幅が低減した。これはカウンタ重量 $M_{c}$ の付加による系全体としての重量増大 の影響を受けているものと考えられる.ここで可動部の運動が起振源となりその強制外力が指示部である固定台 に伝わると考えると, 図 19 （a）（b）中の11のような直進軸の動バランスより重量比 $\alpha=1.00$ 付近を極小值と， 可動部の質量の増加により式（15）の関係から図 19 (a) (b) 中の(2)のような送り軸モータトルクの増大を生じ,

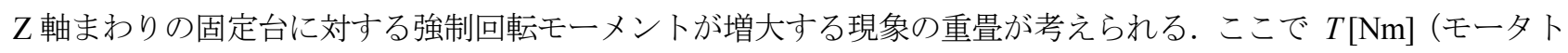
ルク), $I\left[\mathrm{kgm}^{2}\right]$ (慣性モーメント), $a\left[\mathrm{rad} / \mathrm{s}^{2}\right]$ （角加速度）である。ここで式（16），（17）に慣性モーメントの理 論式を示す. $M$ (機械全体の重量), $M_{a}$ (固定台部の重量) $d$ (回転軸からの距離) である. これらの式より, 慣性モーメントは機械の総重量に比例すると考えられる.

$$
\begin{aligned}
& T=I \times a \\
& I=\sum_{i} M_{i} d_{i} \\
& M=M_{s}+M_{c}+M_{a}
\end{aligned}
$$

この運動中に機構から固定台に生じる強制外力（Z 軸の直進成分の強制外力とそのまわりの強制回転モーメン ト）の現象を確認する. 図 20 （a）～（d）はテストスタンドを水平面上のスポンジに設置した時の実験の加速度 の時間波形の計測結果である. ここで図 21, 表 5 に 2 個の加速度センサの計測位置の組み合わせの関係を示す. Case2 3 で Y 軸や Y 軸まわりの振動が顕著とならない事を確認しながら, 図 20 (a) 〜 (d) には Case1 における $\mathrm{X}, \mathrm{Z}$ 軸方向の振動の例を示寸．この例は現象を観察しやすいように，テストスタンドにおける台形波の 1 往復 動作の加速度の時間軸波形である.

図 20 (a) における振動は, 図 21 中の A と C の 2 箇所の X 軸方向の振動であるため Z 軸まわりテストスタン ド自身の回転モーメントを示寸と考えられる. ここで図 20(a)の $t=1.5 \mathrm{~s}$ 直後の残留振動を拡大寸ると図 20 (b) に 示すように逆位相となっており, 図 20 (c) に示寸ように重量比 $\alpha$ を増加させると振幅が大きくなっていること からも式 (15) の関係によってテストスタンド全体がボールねじ軸すなわち Z 軸まわりで回転振動していると考 えられる．またその周期より周波数は $11 \mathrm{~Hz}$ であることもわかる，Z軸方向の振動においては，図 20 (d) におけ る可動部の総重量が実験において最小となる $\alpha=0.15$ においても $t=0.6 \mathrm{~s}$ 直後に $\mathrm{A}$ 点においては周波数 $11 \mathrm{~Hz}$ の残留 振動が見られおり，Z軸まわりの回転振動との連成が存在することもわかる. その一方で Z 軸上 B 点の Z 方向の 振動は可動部の総重量を増大させた $\alpha=1.00$ においてもその残留振動は見られないため, 回転振動は Z 軸まわり で生じていることもわかる.

図 8 （a）で示寸静的な釣合い点 $(\alpha=1.00)$ は直進方向の力の釣合いであり，その効果は式（18）から（22）に 示す直進方向の強制外力との関係が深いものと考えられる. その一方で, 可動部が運動する時に生じる強制回転 モーメントは総重量との関係が深く, かつ図 20(d)でも示されているように Z 軸上でない箇所においては連成に よる影響による振動も生じる. したがって, 図 19 に示すように機構の各運動方向の支持剛性も考慮して, 総合的 にスピンドル部の運動と支持部の運動の合成した振動が低減するように重量比 $\alpha$ を 1 の範囲で設定する必要 があることがわかった。

$$
\begin{aligned}
& -z_{c}=z_{s}=z \\
& F_{c}=M_{c} \ddot{z}_{c}=-\alpha M_{s} \ddot{z} \\
& F_{S}=M_{s} \ddot{z}_{s}=M_{s} \ddot{z}
\end{aligned}
$$




$$
\begin{aligned}
& F=F_{c}+F_{s}=M \ddot{z}_{1} \\
& \ddot{z}_{1}=\frac{(1-\alpha) M_{s}}{M} \ddot{z}
\end{aligned}
$$

$z$ : 系の全体座標系の $\mathrm{z}$ 成分, $M$ : 系全体の質量, $F$ : カウンタ部とスピンドル部の外力の和, 添字の $\mathrm{s}, \mathrm{c}$ はス ピンドル部，カウンタ部を示し， $z_{1}$ : 系の重心の $\mathrm{z}$ 成分，である.

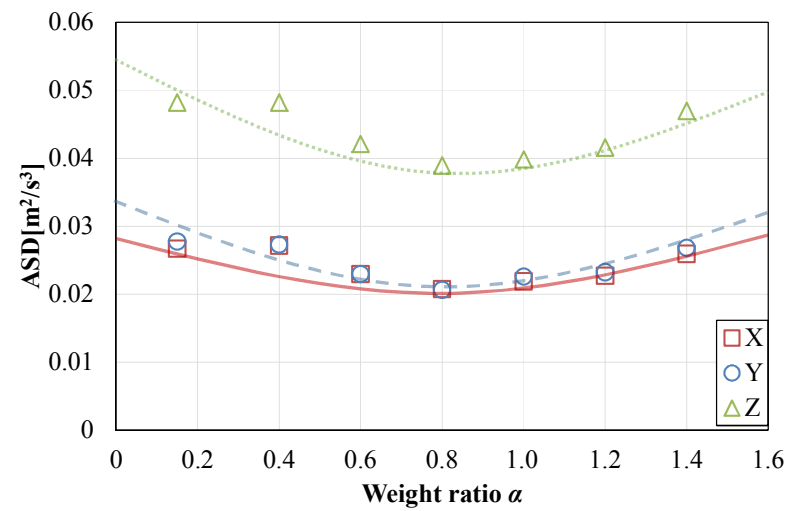

(a) $2.2 \mathrm{~Hz}$ (X,Y,Z-axis)

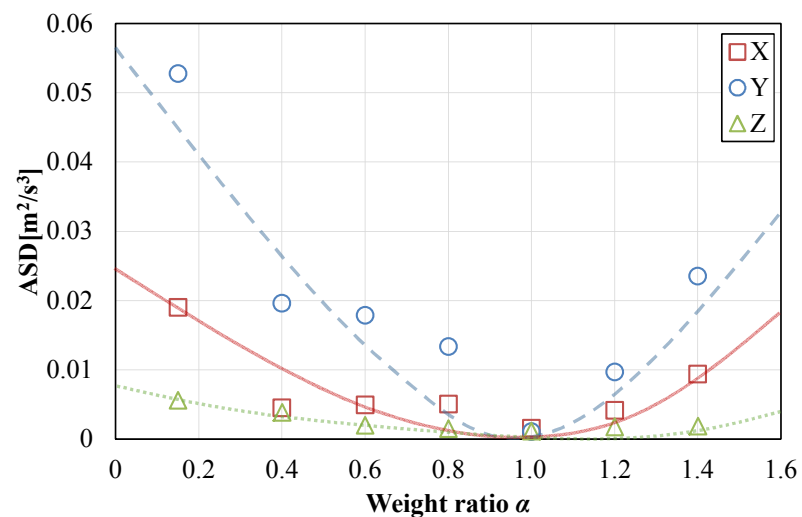

(b) $11 \mathrm{~Hz}$ (X,Y,Z-axis)

Fig. 17 Relationship between ASD and weight ratio of fixed table (Teststand).

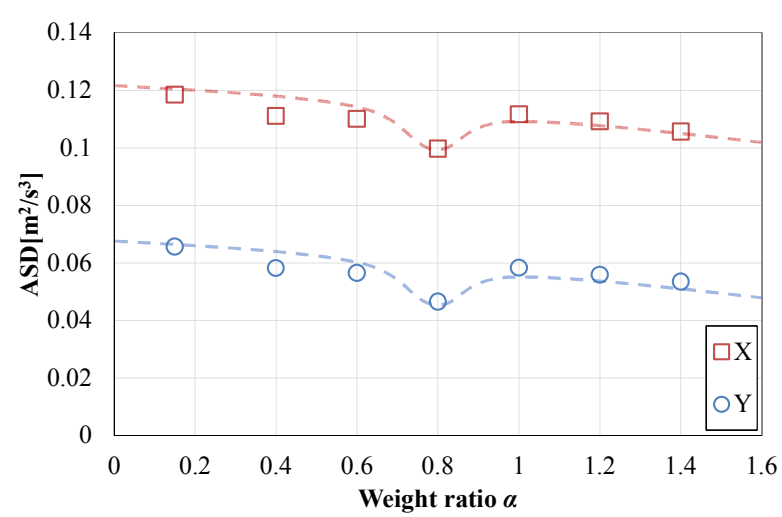

(a) $2.2 \mathrm{~Hz}$ (X,Y-axis)

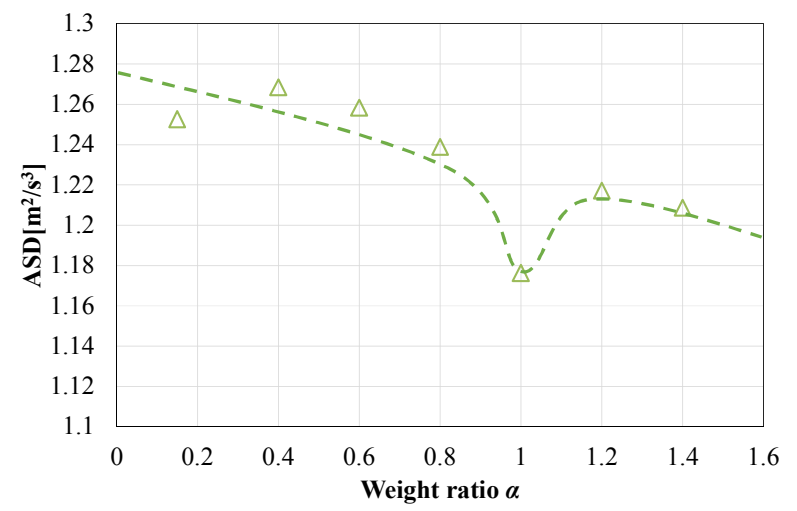

(b) $11 \mathrm{~Hz}$ (Z-axis)

Fig. 18 Relationship between ASD and weight ratio of spindle (Teststand).

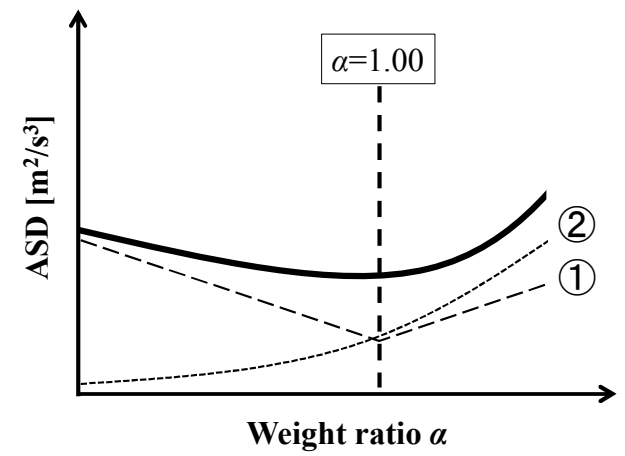

(a) Spindle

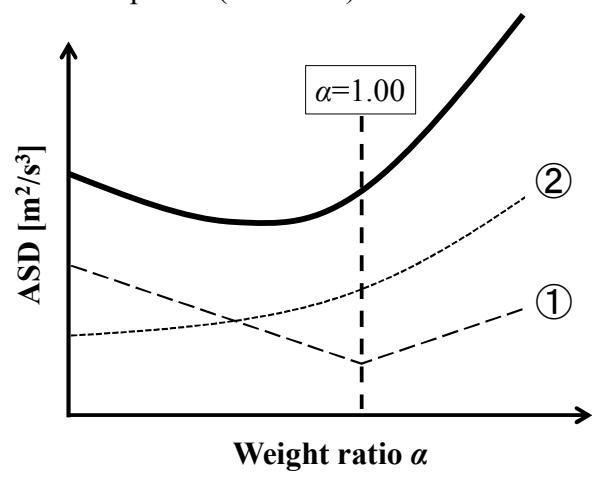

(b) Housing

Fig. 19 Combined vibration model. 


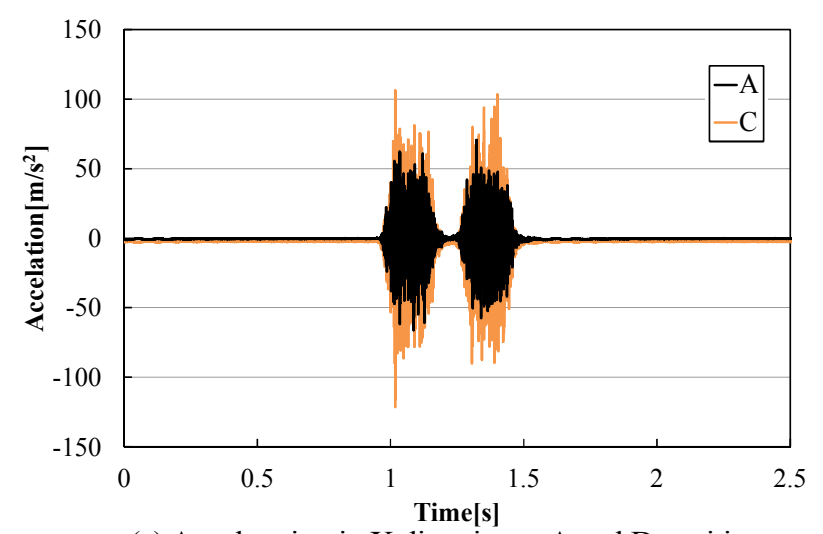

(a) Acceleration in $\mathrm{X}$ direction at $\mathrm{A}$ and $\mathrm{D}$ positions

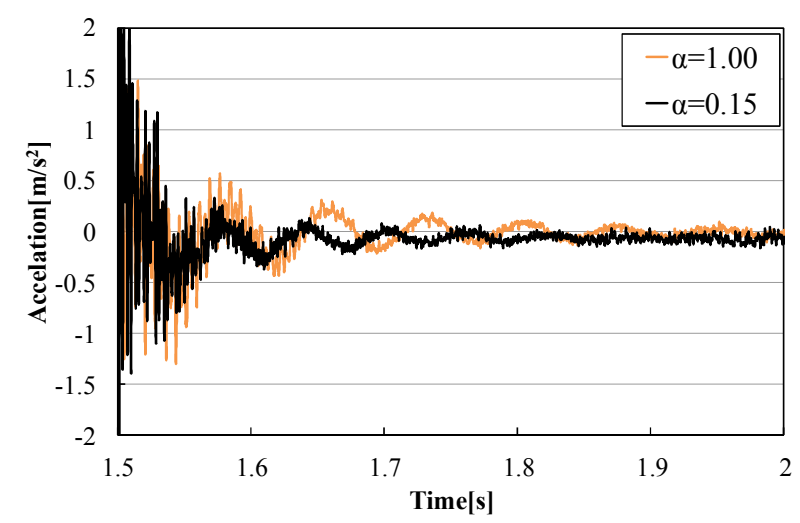

(c) Influence of weight ratio on acceleration in $\mathrm{X}$ direction at A position

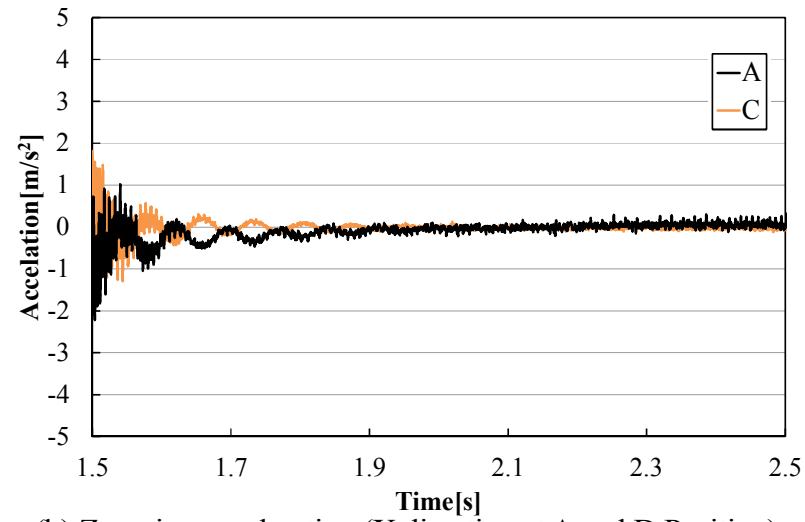

(b) Zooming acceleration ( $\mathrm{X}$ direction at $\mathrm{A}$ and $\mathrm{D}$ Position)

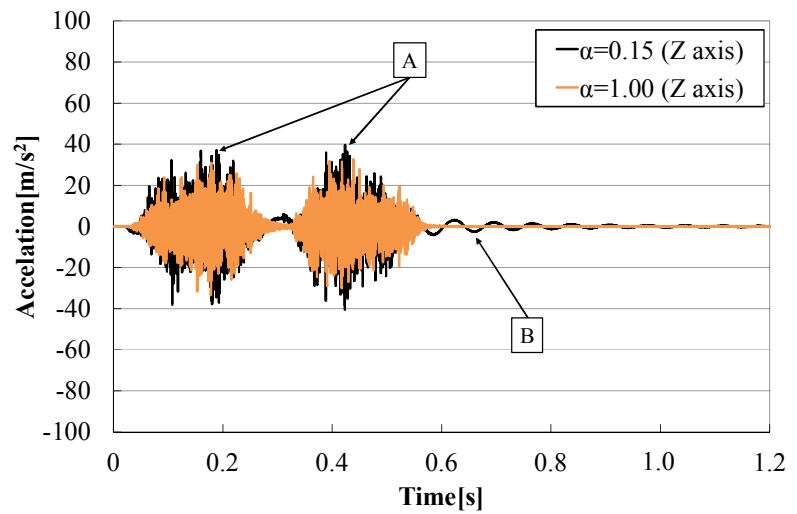

(d) Acceleration in $\mathrm{Z}$ direction at $\mathrm{A}$ and $\mathrm{B}$ positions

Fig. 20 Time line of acceleration of teststand on sponge at measured positions in Fig. 21.

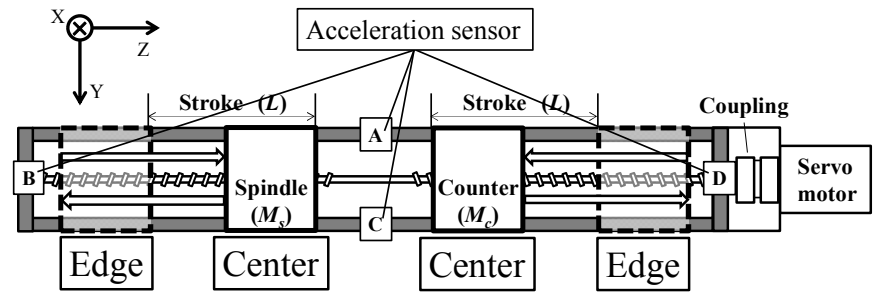

Table 5 Experimental conditions.

\begin{tabular}{c|c|c}
\hline \hline \multicolumn{3}{c}{ Position of the acceleration sensor } \\
\hline Case1 & A & C \\
\hline Case 2 & B & C \\
\hline Case 3 & B & D \\
\hline
\end{tabular}

Fig. 21 Measurement positions of teststand on sponge.

\section{$4 \cdot 3$ 工作機械の Z 軸の運動時で生じる強制外力に起因する振動}

前節の結果も考慮して，工作機械に図 5 に示寸ようなノンステップ動作をさせ， Z 軸送り機構の運動により生 じる強制外力に起因する振動を調べる．図 1(a)に示すように，スピンドル部，およびZ 軸の送り機構を支持する ガイド付近の筐体における X, Y , Z 軸の ASD を計測した. 図 22 (a) (b) に一例として台形波動作時の重量比 $\alpha=0.12,1.11$ におけるスピンドル部の Y 軸, 筐体部の Z 軸方向の ASD を示す. $4 \cdot 2 \cdot 2$ 項と同様に動作周期の 強制振動を確認するため, 図 23 にドリルの位置と時間の関係を示す. 図 23 より, Z 軸送り運動の往復の動作周 期は約 $165 \mathrm{~ms}$ でその周波数は $6.1 \mathrm{~Hz}$ であり，図 22 における $6.75 \mathrm{~Hz}$ 振動に着目した。振幅と重量比の関係を図 24 （a）（b）に示寸. 図24（a）よりスピンドル部の $6.75 \mathrm{~Hz}$ の振動は重量比 $\alpha=1.00$ において最小值を示した. また，図 24 (b) より筐体の $6.75 \mathrm{~Hz}$ の振動は重量比 $\alpha=0.66$ において最小值を示した. すなわち，前節と定性 的に結果が一致しており $\alpha$ を 0 1 の範囲で適切に設定することで, スピンドル部と支持部の振動における相対運 動の振幅を低減できることがわかった. 


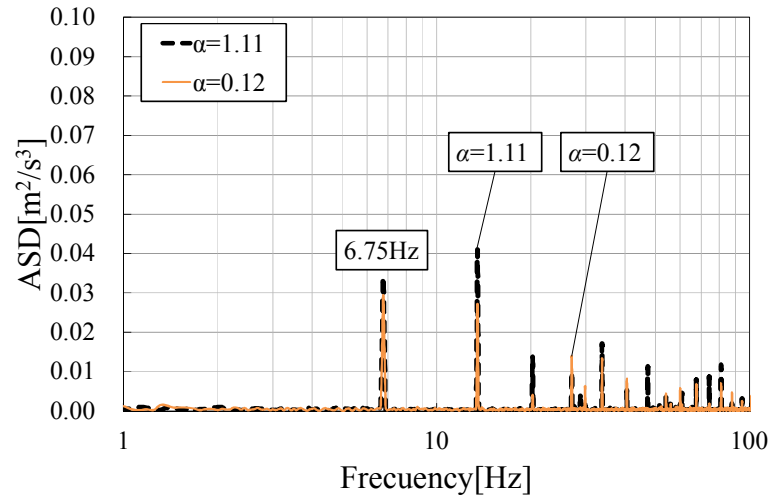

(a) Spindle(Y-axis)

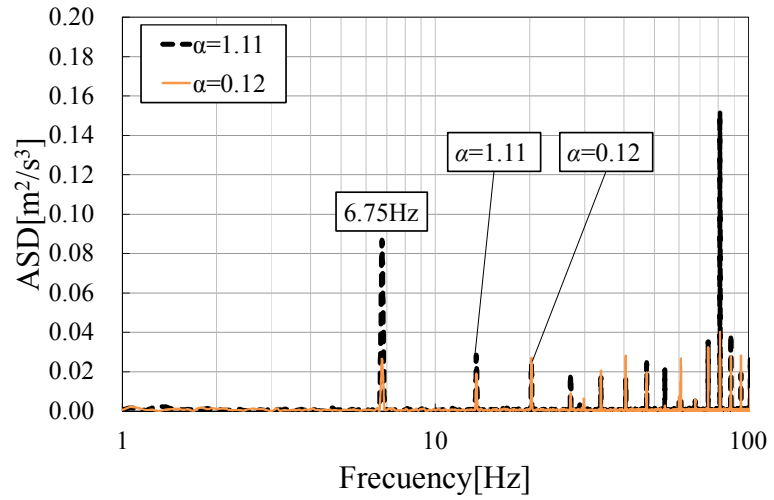

(b) Housing(Z-axis)

Fig. 22 ASD of machine tool

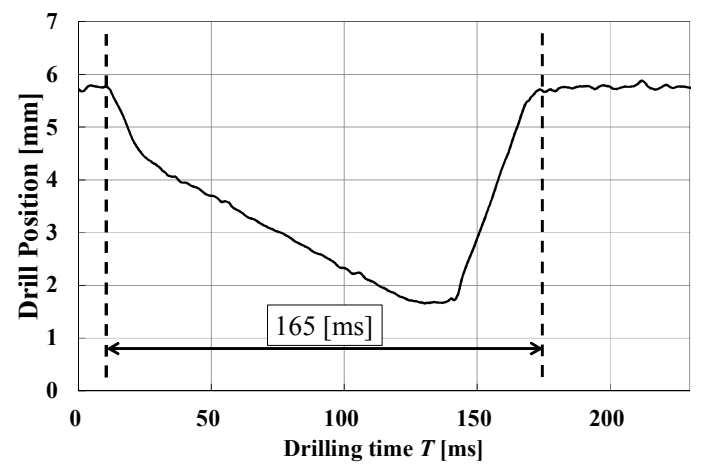

Fig. 23 Drill position.

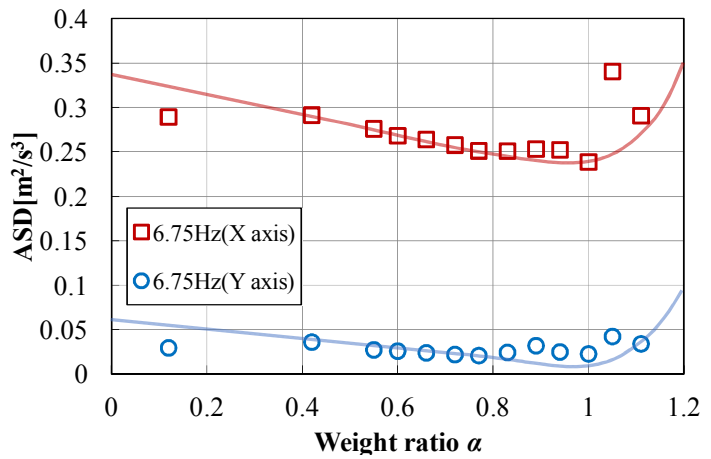

(a) Spindle $(6.75 \mathrm{~Hz})$

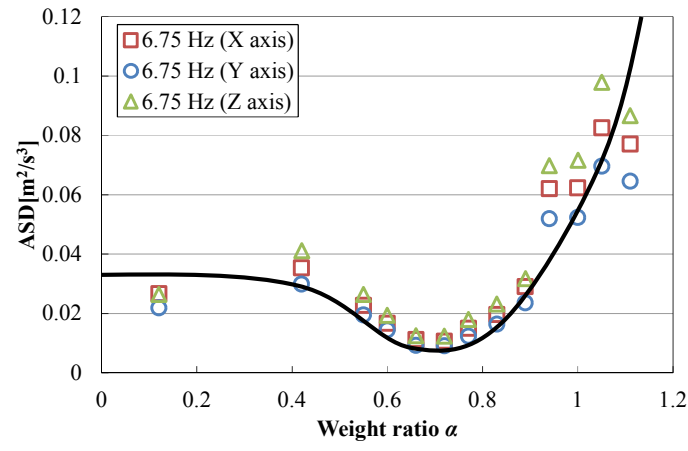

(b) Housing $(6.75 \mathrm{~Hz})$

Fig. 24 Relationship between ASD and weight ratio (Machine tool).

\section{$4 \cdot 4$ 加工時におけるカウンタバランス機構が穴位置精度へ及ぼす影響}

加工時にはドリル先端および工作物テーブル間の相対的な振動変位が重要になるかと考えられる. 図 24 の結果 より, ドリル先端に近いスピンドルの振動は $\alpha=1.00$, テーブル側に近い筐体の振動は $\alpha=0.66$ で極小值を示して いる. そこで重量比 $\alpha$ の条件を 0.12 (カウンタ不積載時)，0.66，1.00の 3 条件において実加工を遂行して，その 影響を調べた. 加工条件は表 2 である. 1 本のドリルで連続加工した 3000 穴の穴位置精度の測定結果を図 25 (a) ～(c), 加工前後のドリル先端の逃げ面の様子を図 26 (a) ～（d）に示す．また 3.2.2 節の手法で算出した穴位置 精度を表 6, 磨耗比率（=加工後の逃げ面の面積／加工前の逃げ面の面積）を表 7 に示寸．また図 26 中には逃げ 面の輪郭線も合わせて示す．ここで逃げ面は平面であるのでカメラ同軸光源からの反射光量が最大となるドリル の姿勢を探し, その法線とカメラの光軸が一致するようにした後, 図 26(d)に示すように逃げ面の全体が白く写る ようにして撮影と計測をした. 加工後の逃げ面の面積はカメラの焦点が一致して明確に写る箇所の輪郭内とした

(例えば，図26(a)なら画像のボケが生じていない箇所の輪郭内の面積). 図 25 より, 重量比 $\alpha=1.00$ において穴 位置精度が悪化していることがわかる. 寸なわち, 図 8 に示寸ように Z 軸の直進方向の静的な釣り合いだけで $\alpha$ 
を設定しても動的な運動やそれらに起因して生じる振動に対して十分な効果を示さないことがわかる. 図 26 (c) では加工後のドリルの片方の刃面にチッピングに近い欠けが生じている. 図 24(b)に示すように $\alpha=1$ では可動重 量の増大で筐体に顕著な振動の増大が生じ，その影響でチッピングを増大させたものと考えられる．その結果， ドリル工具の左右の両刃のバランスが崩れ穴位置精度を悪化させているものと考えられる. 次に, 重量比 $\alpha=0.66$, 0.12 を比較する. 穴位置精度は表 6 に示すように大差は見られなかった. これは両者とも左右の両刃で均等に工 具の摩耗が進行しており $\alpha=1.00$ のようなアンバランスは生じなかったためと考えられる. そこでさらに表 7 に 示寸工具の磨耗率に着目すると, 重量比 $\alpha=0.12$ におけるドリル磨耗比率はチッピングが生じていた重量比 $\alpha=$ 1.00 と同程度の值を示すことがわかる.すなわち図 24(a)(b)で示すように, $\alpha=1$ ほどではないが, $\alpha=0.12$ は $\alpha=0.66$ に比べて若干の振動の増大が見られ，それらの影響でマイクロチッピングが集積して摩耗の増大を招いているも のと考えられる.

以上より，左右ボールねじ駆動カウンタバランス機構を有する工作機械において，スピンドル部，筐体に生じ る振動が加工穴の位置精度, 工具摩耗に与える影響についても調べた. その結果, 適切なカウンタ重量を選定 (本 報の実験の設定では重量比 $\alpha=0.66)$ することで, 極小径マイクロドリル加工において穴位置精度の向上, ドリ ル摩耗・チッピングの抑制に効果を確認できた，すなわち提案する機構は，超高速スピンドルを搭載して遂行さ れる Z 軸に高速往復運動を必要とするマイクロドリル加工用の工作機械に一定の効果が期待できることがわかっ た.

Table 6 Hole position accuracy.

\begin{tabular}{c|c}
\hline \hline Weight ratio $\alpha$ & Hole position accuracy $[\mu \mathrm{m}]$ \\
\hline 0.12 & 12.6 \\
\hline 0.66 & 12.1 \\
\hline 1.00 & 18.2 \\
\hline
\end{tabular}

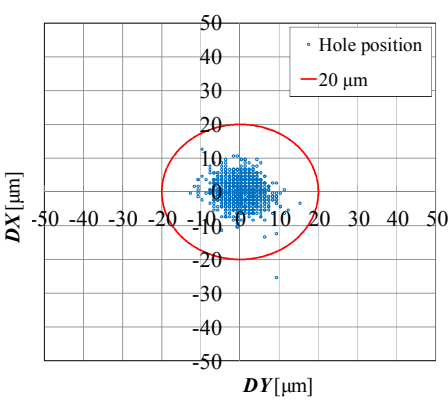

(a) $\alpha=0.12$

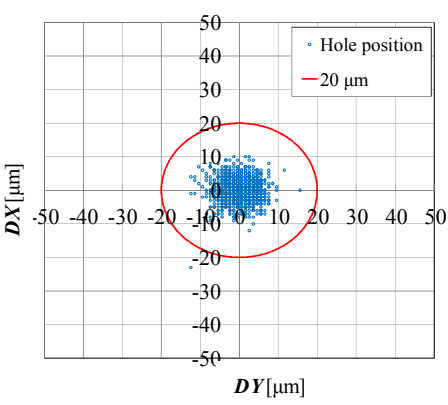

(b) $\alpha=0.66$
Table 7 Wear ratio of drill.

\begin{tabular}{c|c|c}
\hline \hline Weight ratio $\alpha$ & Total area $\left[\mu \mathrm{m}^{2}\right]$ & Wear area [\%] \\
\hline Unused drill & 66825 & 0 \\
\hline 0.12 & 35873 & 46 \\
\hline 0.66 & 39686 & 41 \\
\hline 1.00 & 35960 & 46 \\
\hline
\end{tabular}

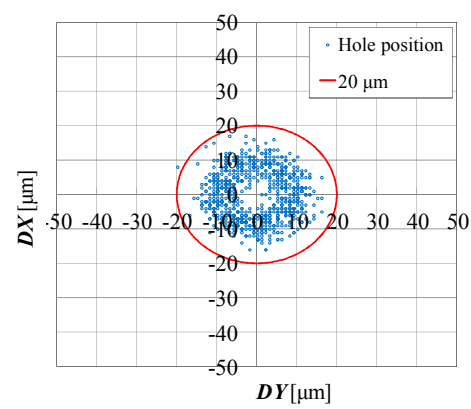

(c) $\alpha=1.00$

Fig. 25 Hole position error (Non-step drilling).

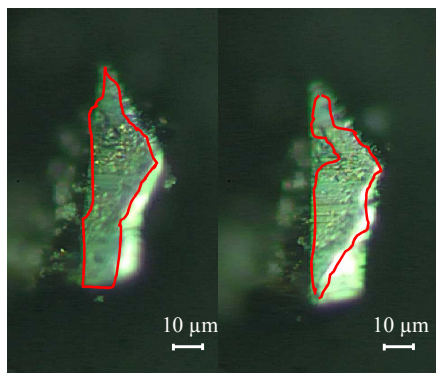

(a) $\alpha=0.12$

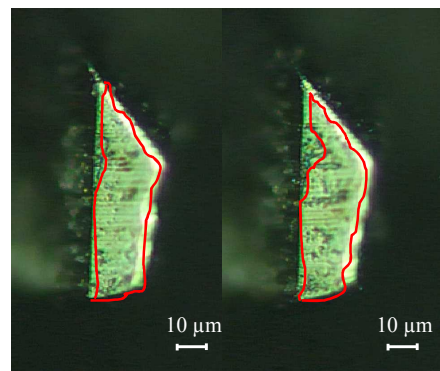

(b) $\alpha=0.66$

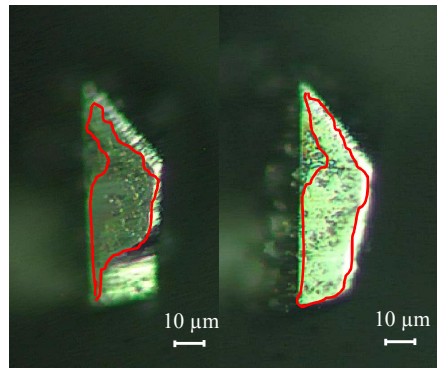

(c) $\alpha=1.00$

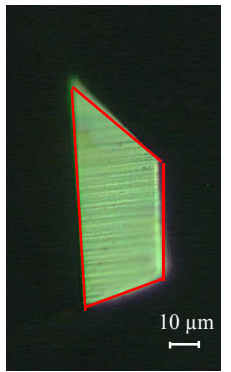

(d)Unused drill

Fig. 26 Flank face of drill edge. 


\section{5. 結 言}

超高速回転（毎分 160 万回転以上）スピンドルを搭載し，短ストロークかつ高速で $\mathrm{Z}$ 軸送りステップ動作等を 必要とする場合において，左右ボールねじを応用したカウンタバランス制振機構を搭載した穴あけ用工作機械を 提案した. 特にその基礎研究として提案する送り機構をモデル化して周波数応答を求め, 各種の振動特性の解析 と考察を遂行し，さらに実加工も遂行してその効果を確認した，その結果，次の結論を得た.

1. Z 軸方向の左右ボールねじカウンタバランスの送り運動を 4 慣性で直列に接続した Z 軸まわりのねじりと 振動でモデル化する手法を提案できた．その結果, 高周波のサーボ系の共振を含めてカウンタバランス制 振機構のカウンタ部の重量と固有振動数の関係を把握することが可能であることがわかった.

2. 提案するカウンタバランス制振機構を対象にして, 運動中の振動加速度の波形にスペクトログラム解析を 用いる手法は, テーブル位置によるボールねじ部の有効長さの変化に起因する系の固有振動数の変化を明 確化するために有効であることがわかった。

3. 工作機械の本体の固有振動数に近い低周波数域の振動に対しては, 可動部であるスピンドル部とカウンタ 部の重量比（= $\alpha)$ が 1 の場合に直進軸方向の振動成分は最小值を示寸が，その一方で Z 軸まわりの回転 モーメントによる振動成分は可動部の総重量の増加で増大寸る.したがって，両者のそれぞれの支持剛性 の組み合わせにより適切なカウンタ重量の設定值が異なり, その重量比 $\alpha=0 \sim 1$ の間に最適值が存在する ことを示した。

4. 適切に重量比 $\alpha$ を設定した超高速回転スピンドル搭載のプリント基板穴あけ工作機械で極小径マイクロ ドリルの実加工を遂行した結果，ドリル摩耗・チッピングの低減および穴位置精度の向上において制振の 効果が確認できた.

\section{文献}

廣坦俊樹，青山栄一，小川圭二，大塚剛史，野尻啓史，超高速スピンドルを用いたプリント基板における極小径 ドリル加工穴の熱損傷と最適加工条件の考察，日本機械学会論文集 C 編, Vol.74, No.743(2008),pp.1894-1900.

廣垣俊樹, 青山栄一, 小川圭二, 竹田豊, 野口直弥, 応答曲面法を用いたプリント基板の極小径ドリル加工によ る高速微小送りステップ動作の最適化，日本機械学会論文集 C 編, Vol.78, No.788(2012),pp.1280-1294.

今村誠, 広瀬和弘, マイクロドリルの技術動向と応用 (特集マイクロ加工用工具の最先端技術), 砥粒加工学会誌, Vol.49, No.10(2005),pp.550-553.

岩田一明, 森脇俊道, 星川雅之, 高速微小深穴ドリル加工の基礎的研究, 精密機械, Vol. 49, No.2(1983),pp.240-246. 松原厚，精密位置決め・送り系設計のための制御工学，森北出版(2013),pp.123-140.

野村行弘, 呂建明, 関屋大雄, 谷萩隆嗣, 観測信号のスペクトログラム上の特徵量に基づく音声領域と雑音領域 との判別を用いた音声強調，電気学会論文集 C 編，Vol.124, No.11(2004),pp.2310-2319.

佐藤崇弘, 田中久隆, 佐藤昌彦, 小出隆夫, 回転振れのある小径ドリルの加工挙動（ドリル求心性に及ぼす切れ はの向きの影響)，砥粒加工学会誌, Vol. 58, No.7 (2014),pp.451-456.

寺林隆夫, 大幸洋一, 前田幸男, 栘田正美，プリント基板の小径ドリル加工（第4 報）（ドリル送りの瞬間停止機 構を用いたドリル折損防止加工の試み)，精密工学会誌，Vol. 68, No.4(2002),pp.556-560

Watanabe, H., Tsuzaka, H. and Masuda, M., Microdrilling for printed circuit boards (PCBs) - Influence of radial run-out of micro-drills on hole quality, Precision Engineering, Vol.32 (2008), pp.329-335.

吉川英一郎, 藤澤彰利, 岡村康弘, 東條毅浩, プリント基板加工用アルミ表面潤滑処理材, 神戸製鋼技報, Vol.57, No.1(2007),pp.22-26.

\section{References}

Hirogaki, T., Aoyama E., Ogawa, K., Otsuka, T. and Nojiri, H., Study on thermal damage of micro diameter hole drilled by super-high-speed spindle in PWB and optimum drilling condition, Transactions of the Japan Society of Mechanical Engineers, Series C, Vol. 74, No. 743 (2008),pp.1894-1900 (in Japanese).

Hirogaki, T., Aoyama, E., Ogawa, K., Takeda, Y. and Noguchi, N., Optimization of step micro drilling motion with high speed and short stroke in printed wiring boards by response surface method, Transactions of the Japan Society of Mechanical Engineers, Series C, Vol.78, No.788(2012),pp.1280-1294(in Japanese). 
Imamura, M. and Hirose, K., Technical trend and application of the microdrill (Advanced technique of the tool for special feature micro processing), Journal of Japan Society for Abrasive Technology, Vol. 49, No. 10(2005),pp.550-553(in Japanese).

Iwata, K., Moriwaki, T. and Hoshikawa, M., Fundamental study of high speed micro deep drilling, Journal of Japan Society for Precision Engineering, Vol. 49, No.2(1983),pp.240-246(in Japanese).

Matsubara, A., Design and Control of Precision Positioning and Feed Drive systems, Morikita Publishing Co., Ltd.(2013), pp.123-140(in Japanese).

Nomura, Y., Lu, J., Sekiya, H. and Yahagi, T, Speech enhancement based on the dominant classification between speech and noise using feature data in spectrogram of observation signal, Transactions of the Japan Society of Mechanical Engineers, Series C, Transactions of The Institute of Electrical Engineers of Japan, Series C, Vol.124, No.11(2004),pp.2310-2319(in Japanese).

Sato, T., Tanaka, H., Sato, M. and Koide, T., Drilling behavior of run-out micro drill (Effect of cutting edge orientation on centripetal characteristics), Journal of the Japan Society for Abrasive Technology, Vol. 58, No.7(2014),pp.451-456(in Japanese).

Terabayashi, T., Daikoh, Y., Maeda, Y. and Masuda, M., Micro drilling of printed circuit boards (4 ${ }^{\text {th }}$ Report) (A breakage prevention drilling using a quick stop mechanism of drill feed), Journal of Japan Society for Precision Engineering, Vol. 68, No.4(2002),pp.556-560(in Japanese).

Watanabe, H., Tsuzaka, H. and Masuda, M., Microdrilling for printed circuit boards (PCBs) - Influence of radial run-out of micro-drills on hole quality, Precision Engineering, Vol.32 (2008), pp.329-335.

Yoshikawa, E., Fujisawa, A., Okamura, Y. and Tozyo, H., Aluminum surface lubrication processing materials for printed circuit board processing, Technical report of Kobe Steel, Vol.57, No.1(2007),pp.22-26(in Japanese). 